\title{
Chelatococcus daeguensis sp. nov., isolated from wastewater of a textile dye works, and emended description of the genus Chelatococcus
}

Correspondence
Jung-Hoon Yoon
jhyoon@kribb.re.kr

\author{
Jung-Hoon Yoon, ${ }^{1}$ So-Jung Kang, ${ }^{1}$ Wan-Taek Im, ${ }^{2}$ Sung-Taik Lee ${ }^{2}$ \\ and Tae-Kwang $\mathrm{Oh}^{1}$ \\ ${ }^{1}$ Korea Research Institute of Bioscience and Biotechnology (KRIBB), PO Box 115, Yusong, \\ Daejeon, Republic of Korea
2Department of Biological Science, Korea Advanced Institute of Science and Technology, 373-1 Guseong-dong, Yuseong-gu, Daejeon 305-701, Republic of Korea

\begin{abstract}
A Gram-negative, non-spore-forming, rod-shaped bacterial strain, $\mathrm{K}^{106^{\top}}$, was isolated from wastewater collected from a textile dye works in Korea. Strain $\mathrm{K}_{106}{ }^{\top}$ grew optimally at $\mathrm{pH}$ 7.07.5 and $30-37{ }^{\circ} \mathrm{C}$ in the presence of $0-1.0 \%(\mathrm{w} / \mathrm{v}) \mathrm{NaCl}$. A phylogenetic tree based on $16 \mathrm{~S}$ rRNA gene sequences showed that strain $\mathrm{K}_{106}{ }^{\top}$ joined the type strain of Chelatococcus asaccharovorans with a bootstrap resampling value of $99.9 \%$. The predominant ubiquinone of strain $\mathrm{K} 106^{\top}$ was Q-10. The fatty acid profile of strain $\mathrm{K} 106^{\top}$ was similar to that of $C$. asaccharovorans DSM $6462^{\top}$. Major polar lipids of strain $\mathrm{K}_{106}{ }^{\top}$ and C. asaccharovorans DSM $6462^{\top}$ were phosphatidylcholine, phosphatidylglycerol, phosphatidylethanolamine, two aminolipids and two unidentified phospholipids. sym-Homospermidine, spermidine and putrescine were major polyamines. The DNA G+C content was 68.3 mol\%. Strain K106 exhibited $16 \mathrm{~S}$ rRNA gene sequence similarity of $96.6 \%$ to the type strain of $C$. asaccharovorans. DNA-DNA relatedness data and differential phenotypic properties, particularly differences in cell morphology and the ability to utilize nitrilotriacetate, demonstrated that strain $\mathrm{K}_{106}{ }^{\top}$ can be differentiated from C. asaccharovorans. On the basis of phenotypic, phylogenetic and genetic data, strain $\mathrm{K}_{106}{ }^{\top}$ represents a novel species of the genus Chelatococcus, for which the name Chelatococcus daeguensis sp. nov. is proposed. The type strain is $\mathrm{K}_{106}{ }^{\top}\left(=\mathrm{KCTC} 12979^{\top}\right.$ $=$ CCUG $54519^{\top}$ ).
\end{abstract}

The genus Chelatococcus was proposed by Auling et al. (1993) with Chelatococcus asaccharovorans as the sole recognized species of the genus. Phylogenetic analysis based on $16 \mathrm{~S}$ rRNA gene sequences showed that the genus Chelatococcus falls within the Alphaproteobacteria (Auling et al., 1993; Lee et al., 2005). In this study, we describe a bacterial strain, $\mathrm{K} 106^{\mathrm{T}}$, which was isolated from wastewater of a textile dye works in Korea. 16S rRNA gene sequence comparison indicated that this strain is most closely related phylogenetically to the genus Chelatococcus. However, cells of strain $\mathrm{K}_{106^{\mathrm{T}}}$ were rod-shaped, unlike those of $C$. asaccharovorans. Accordingly, the aim of the present study was to determine the exact taxonomic position of strain $\mathrm{K}_{106^{\mathrm{T}}}$ by a polyphasic characterization that included determination of phenotypic and chemotaxonomic properties, detailed phylogenetic analysis based on 16S rRNA gene sequences and genetic analysis.

Abbreviation: NTA, nitrilotriacetate.

The GenBank/EMBL/DDBJ accession number for the 16S rRNA gene sequence of strain $\mathrm{K} 106^{\top}$ is EF584507.
Strain $\mathrm{K}_{106^{\mathrm{T}}}$ was isolated by means of the standard dilution-plating technique on trypticase soy agar (TSA; Difco) at $30{ }^{\circ}$ C. C. asaccharovorans DSM $6462^{\mathrm{T}}$, which was used as a reference strain for DNA-DNA hybridization and chemotaxonomic and phenotypic analyses, was obtained from the Deutsche Sammlung von Mikroorganismen und Zellkulturen (DSMZ), Braunschweig, Germany. The morphological properties of strain $\mathrm{K}_{106}{ }^{\mathrm{T}}$ and C. asaccharovorans DSM $6462^{\mathrm{T}}$ were investigated on TSA, R2A agar (Difco) and nutrient agar (NA; Difco). The physiological and biochemical characteristics of strain $\mathrm{K} 106^{\mathrm{T}}$ were investigated using routine cultivation on TSA at $37{ }^{\circ} \mathrm{C}$. Cell morphology was examined by light microscopy (Nikon E600) using cells from exponentially growing cultures. The Gram reaction was determined using the bioMérieux Gram stain kit according to the manufacturer's instructions. Growth at various temperatures $\left(4-55^{\circ} \mathrm{C}\right)$ was measured on TSA. The $\mathrm{pH}$ range for growth was determined in nutrient broth (Difco) adjusted, prior to sterilization, to various $\mathrm{pH}$ values $(\mathrm{pH} 4.5-10.5$ at intervals of $0.5 \mathrm{pH}$ units) by the addition of $\mathrm{HCl}$ or $\mathrm{Na}_{2} \mathrm{CO}_{3}$. 
Growth in the absence of $\mathrm{NaCl}$ and at various $\mathrm{NaCl}$ concentrations $(0.5 \%, \mathrm{w} / \mathrm{v}$, and $1.0-7.0 \%, \mathrm{w} / \mathrm{v}$, at intervals of $1.0 \%$ ) was investigated using trypticase soy broth (TSB) prepared according to the formula of the Difco medium except that $\mathrm{NaCl}$ was excluded from the medium formula. Growth under anaerobic conditions was determined after incubation in an anaerobic chamber on TSA and on TSA supplemented with potassium nitrate $(0.1 \%, \mathrm{w} / \mathrm{v})$, both of which had been prepared anaerobically under a nitrogen atmosphere. Catalase and oxidase activities and hydrolysis of casein, gelatin, hypoxanthine, starch, Tweens 20, 40, 60 and 80, tyrosine, urea and xanthine were determined as described by Cowan \& Steel (1965). Hydrolysis of aesculin and nitrate reduction were studied as described previously (Lányí, 1987). Susceptibility to antibiotics was tested on TSA plates using discs containing the following antibiotics in the amounts indicated: polymyxin B, $100 \mathrm{U}$; streptomycin, $50 \mu \mathrm{g}$; penicillin $\mathrm{G}, 20 \mathrm{U}$; chloramphenicol, $100 \mu \mathrm{g}$; ampicillin, $10 \mu \mathrm{g}$; cephalothin, $30 \mu \mathrm{g}$; gentamicin, $30 \mu \mathrm{g}$; novobiocin, $5 \mu \mathrm{g}$; tetracycline, $30 \mu \mathrm{g}$; kanamycin, $30 \mu \mathrm{g}$; lincomycin, $15 \mu \mathrm{g}$; oleandomycin, $15 \mu \mathrm{g}$; neomycin, $30 \mu \mathrm{g}$; carbenicillin, $100 \mu \mathrm{g}$. Utilization of various substrates, enzyme activities and other physiological and biochemical properties were tested by using the API 20E, API 20NE, API 50CH and API ZYM systems (bioMérieux). The cells were suspended in AUX medium according to the manufacturer's instructions to inoculate the API $50 \mathrm{CH}$ system. Utilization of nitrilotriacetate (NTA) was tested with a synthetic medium as described by Egli et al. (1988); C. asaccharovorans DSM $6462^{\mathrm{T}}$ was used as a positive control.

Cell biomass of strain $\mathrm{K} 106^{\mathrm{T}}$ and C. asaccharovorans DSM $6462^{\mathrm{T}}$ for DNA extraction and for the analyses of isoprenoid quinones, polar lipids and polyamines was obtained from cultivation in TSB (Difco) at 37 and $30{ }^{\circ} \mathrm{C}$, respectively. Chromosomal DNA was isolated and purified according to the method described by Yoon et al. (1996), with the exception that RNase T1 was used in combination with RNase A to minimize contamination with RNA. The $16 \mathrm{~S}$ rRNA gene was amplified by PCR using two universal primers as described previously (Yoon et al., 1998). Sequencing of the amplified 16S rRNA gene and phylogenetic analysis were performed as described by Yoon et al. (2003). Isoprenoid quinones were extracted according to the method of Komagata \& Suzuki (1987) and analysed using reversed-phase HPLC and a YMC ODS-A $(250 \times 4.6 \mathrm{~mm})$ column. For cellular fatty acid analysis, cell mass of strain $\mathrm{K} 106^{\mathrm{T}}$ and C. asaccharovorans DSM $6462^{\mathrm{T}}$ was harvested from TSA plates after incubation for 5 days at $30{ }^{\circ} \mathrm{C}$. The fatty acids were extracted and fatty acid methyl esters were prepared according to the standard protocol of the MIDI/Hewlett Packard Microbial Identification System (Sasser, 1990). Polar lipids were extracted according to the procedures described by Minnikin et al. (1984) and identified by two-dimensional TLC followed by spraying with appropriate detection reagents (Minnikin et al., 1984; Komagata \& Suzuki, 1987).
The presence of phosphatidylcholine was identified by spraying with Dragendorff's reagent (Sigma). Polyamines were extracted and analysed as described by Busse \& Auling (1988) and Schenkel et al. (1995). The DNA G + C content was determined by the method of Tamaoka \& Komagata (1984) with the modification that the DNA was hydrolysed and the resultant nucleotides were analysed by reversedphase HPLC. DNA-DNA hybridization was performed fluorometrically by the method of Ezaki et al. (1989) using photobiotin-labelled DNA probes and microdilution wells. Hybridization was performed with five replications for each sample. The highest and lowest values obtained in each sample were excluded, and the means of the remaining three values are quoted as DNA-DNA relatedness values.

Morphological, cultural, physiological and biochemical characteristics of strain $\mathrm{K} 106^{\mathrm{T}}$ are given in the species description or are shown in Table 1. Cells of strain $\mathrm{K}_{106}{ }^{\mathrm{T}}$ were rods on TSA, R2A agar and NA, whereas cells of $C$. asaccharovorans DSM $6462^{\mathrm{T}}$ were cocci on these media. The almost-complete 16S rRNA gene sequence of strain K106 ${ }^{\mathrm{T}}$ determined in this study comprised $1442 \mathrm{nt}$, representing approximately $96 \%$ of the Escherichia coli $16 \mathrm{~S}$ rRNA gene sequence. In the neighbour-joining phylogenetic tree based on 16S rRNA gene sequences, strain $\mathrm{K} 106^{\mathrm{T}}$ joined the lineage comprising the type strain of $C$. asaccharovorans at a bootstrap resampling value of $99.9 \%$ (Fig. 1). The relationship between strain $\mathrm{K}_{106}{ }^{\mathrm{T}}$ and the type strain of $C$. asaccharovorans was maintained in trees based on the maximum-likelihood and maximumparsimony algorithms (Fig. 1). Strain $\mathrm{K}_{106^{\mathrm{T}}}$ exhibited $16 \mathrm{~S}$ rRNA gene sequence similarity of $96.6 \%$ to the type strain of C. asaccharovorans and of less than $93.6 \%$ to other species included in the phylogenetic analysis. The predominant isoprenoid quinone detected in strain $\mathrm{K} 106^{\mathrm{T}}$ was ubiquinone-10 (Q-10), at a peak area ratio of approximately $83 \%$; a significant amount of Q-8 (approx. 15\%) was also detected. Strain $\mathrm{K}_{106^{\mathrm{T}}}$ had a cellular fatty acid profile that contained large amounts of unsaturated, cyclo and hydroxy fatty acids; the major fatty acids $(>10 \%$ total fatty acids) were $\mathrm{C}_{18: 1} \omega 7 c$ and $\mathrm{C}_{19: 0}$ cyclo $\omega 8 c$ (Table 2 ). This fatty acid profile was similar to that of $C$. asaccharovorans DSM $6462^{\mathrm{T}}$ analysed in this study, although there were differences in the proportions of some fatty acids (Table 2). Major polar lipids found in strain K106 ${ }^{\mathrm{T}}$ were phosphatidylcholine, phosphatidylglycerol, phosphatidylethanolamine, two aminolipids and two unidentified phospholipids. The major polar lipids of $C$. asaccharovorans DSM $6462^{\mathrm{T}}$ analysed in this study were the same. Major polyamines detected in this study were symhomospermidine, spermidine and putrescine, as also found in C. asaccharovorans (Auling et al., 1993). The DNA G+C content of strain $\mathrm{K}_{106^{\mathrm{T}}}$ was $68.3 \mathrm{~mol} \%$.

Strain $\mathrm{K} 106^{\mathrm{T}}$ differed from C. asaccharovorans in that its cells were rod-shaped. However, there were no distinct phenotypic, particularly chemotaxonomic, properties to differentiate strain $\mathrm{K} 106^{\mathrm{T}}$ from C. asaccharovorans, as 
Table 1. Differential phenotypic characteristics of strain $\mathrm{K} 106^{\top}$ and C. asaccharovorans DSM $6462^{\top}$

Data were obtained in this study. +, Positive; -, negative ; w, weakly positive. Both strains are positive for catalase, oxidase, acid phosphatase, alkaline phosphatase, esterase (C4), esterase lipase (C8), leucine arylamidase, naphthol-AS-BI-phosphohydrolase, nitrate reduction, hydrolysis of aesculin, utilization of D- and L-arabinose, ribose, D-xylose, glucose, mannose, rhamnose, D-lyxose, D- and L-fucose, gluconate, 2-ketogluconate, 5ketogluconate, adipate and malate and susceptibility to gentamicin, carbenicillin and tetracycline, and negative for $\mathrm{H}_{2} \mathrm{~S}$ production, lysine decarboxylase, ornithine decarboxylase, tryptophan deaminase, lipase (C14), valine arylamidase, cystine arylamidase, trypsin, $\alpha$-chymotrypsin, $\alpha$ galactosidase, $\beta$-galactosidase, $\beta$-glucuronidase, $\alpha$-glucosidase, $\beta$-glucosidase, $N$-acetyl- $\beta$-glucosaminidase, $\alpha$-mannosidase, $\alpha$-fucosidase, hydrolysis of casein, gelatin, starch, hypoxanthine, xanthine, L-tyrosine and Tweens 20, 40, 60 and 80, utilization of erythritol, methyl $\beta$-D-xyloside, dulcitol, mannitol, sorbitol, methyl $\alpha$-D-mannoside, methyl $\alpha$-D-glucoside, $N$-acetylglucosamine, maltose, lactose, melibiose, sucrose, trehalose, inulin, melezitose, raffinose, starch, glycogen, turanose, D-tagatose and D- and L-arabitol, acid production from mannitol, sorbitol, sucrose, melibiose and amygdalin and susceptibility to ampicillin, cephalothin, lincomycin, novobiocin, oleandomycin, polymyxin B and penicillin G.

\begin{tabular}{|c|c|c|}
\hline Characteristic & C. daeguensis $\mathrm{K} 106^{\mathrm{T}}$ & C. asaccharovorans DSM $6462^{\mathrm{T}}$ \\
\hline Cell morphology & Rods & Coccoid to oval \\
\hline Urease & - & + \\
\hline Arginine dihydrolase & + & - \\
\hline \multicolumn{3}{|l|}{ Utilization of: } \\
\hline NTA, phenylacetate & - & + \\
\hline $\begin{array}{l}\text { Glycerol, adonitol, galactose, fructose, inositol, amygdalin, arbutin, aesculin, } \\
\text { salicin, cellobiose, xylitol, gentiobiose, citrate }\end{array}$ & + & - \\
\hline L-Xylose & + & $\mathrm{W}$ \\
\hline Sorbose & $\mathrm{W}$ & - \\
\hline \multicolumn{3}{|l|}{ Acid production from: } \\
\hline Glucose, inositol, arabinose & + & - \\
\hline Rhamnose & $\mathrm{W}$ & - \\
\hline \multicolumn{3}{|l|}{ Susceptibility to: } \\
\hline Streptomycin, chloramphenicol & + & - \\
\hline Kanamycin, neomycin & - & + \\
\hline
\end{tabular}

shown by Auling et al. (1993) and in this study. Accordingly, it seems reasonable that strain $\mathrm{K}_{106^{\mathrm{T}}}$ is classified as a member of the genus Chelatococcus. Strain

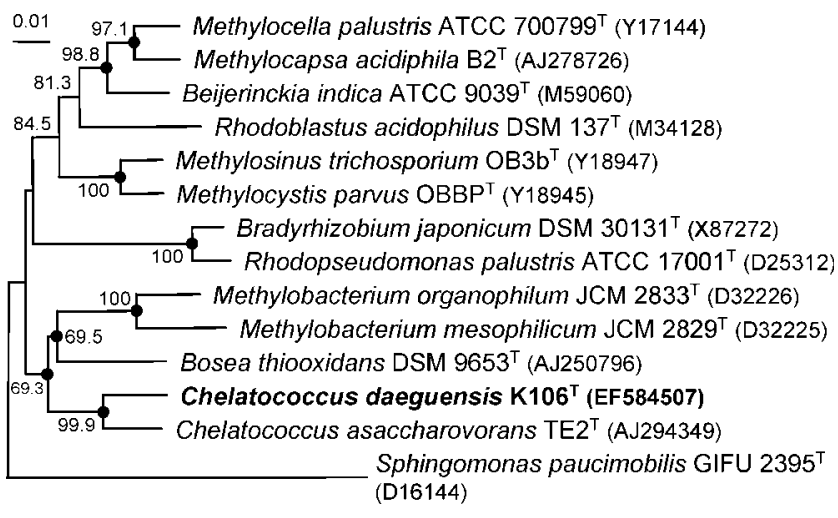

Fig. 1. Neighbour-joining phylogenetic tree based on $16 \mathrm{~S}$ rRNA gene sequences showing the positions of Chelatococcus daeguensis sp. nov. $\mathrm{K} 106^{\top}$ and some other related taxa. Bootstrap values (expressed as percentages of 1000 replications) $>50 \%$ are shown at branching points. Dots indicate that the corresponding nodes were also recovered in trees generated with the maximum-likelihood and maximum-parsimony algorithms. Sphingomonas paucimobilis GIFU $2395^{\top}$ was used as an outgroup. Bar, 0.01 substitutions per nucleotide position.
$\mathrm{K}_{106^{\mathrm{T}}}$ was distinguishable from C. asaccharovorans by differences in cell morphology and several phenotypic characteristics (Table 1). The mean level of DNA-DNA relatedness between strain $\mathrm{K}_{106}{ }^{\mathrm{T}}$ and C. asaccharovorans DSM $6462^{\mathrm{T}}$ was $13 \%$ when their DNAs were used individually as labelled DNA probes for cross-hybridization. The phylogenetic distinctiveness, differential phenotypic properties and DNA-DNA relatedness data are sufficient to categorize strain $\mathrm{K} 106^{\mathrm{T}}$ as a representative of a species that is separate from $C$. asaccharovorans (Wayne et al., 1987; Stackebrandt \& Goebel, 1994). Therefore, on the basis of the data presented, strain $\mathrm{K} 106^{\mathrm{T}}$ represents a novel species of the genus Chelatococcus, for which the name Chelatococcus daeguensis sp. nov. is proposed.

\section{Description of Chelatococcus daeguensis sp. nov.}

Chelatococcus daeguensis (dae.gu.en'sis. N.L. masc. adj. daeguensis of Daegu, Korea, from where the type strain was isolated).

Cells are Gram-negative, non-spore-forming rods (0.3$0.6 \times 1.0-4.0 \mu \mathrm{m})$. Colonies on TSA are circular, convex, smooth, glistening, moderate yellow in colour and $0.7-$ $1.0 \mathrm{~mm}$ in diameter after incubation for 3 days at $37^{\circ} \mathrm{C}$. Optimal temperature for growth is $30-37{ }^{\circ} \mathrm{C}$. Growth occurs at 20 and $51{ }^{\circ} \mathrm{C}$, but not at 15 or $52{ }^{\circ} \mathrm{C}$. Optimal pH for growth is 7.0-7.5; growth occurs at $\mathrm{pH} 5.5$ and 10.0, 
Table 2. Cellular fatty acid compositions of $C$. daeguensis $\mathrm{K} 106^{\top}$ and C. asaccharovorans DSM $6462^{\top}$

Values are percentages of total fatty acids. Fatty acids that represented $<0.5 \%$ in both strains were omitted. ECL, Equivalent chain length. Data were obtained in this study.

\begin{tabular}{|c|c|c|}
\hline Fatty acid & $\begin{array}{l}\text { C. daeguensis } \\
{\mathrm{K} 106^{\mathrm{T}}}\end{array}$ & $\begin{array}{c}\text { C. asaccharovorans } \\
\text { DSM } 6462^{\mathrm{T}}\end{array}$ \\
\hline \multicolumn{3}{|l|}{ Straight-chain } \\
\hline $\mathrm{C}_{16: 0}$ & 2.2 & 8.5 \\
\hline $\mathrm{C}_{17: 0}$ & 0.9 & 0.4 \\
\hline $\mathrm{C}_{18: 0}$ & 1.7 & 0.9 \\
\hline \multicolumn{3}{|l|}{ Unsaturated } \\
\hline $\mathrm{C}_{18: 1} \omega 7 c$ & 64.4 & 47.4 \\
\hline $\mathrm{C}_{20: 1} \omega 7 c$ & 0.4 & 1.4 \\
\hline \multicolumn{3}{|l|}{ Hydroxy } \\
\hline $\mathrm{C}_{18: 1} 2-\mathrm{OH}$ & 3.7 & 0.9 \\
\hline $\mathrm{C}_{18: 0} 3-\mathrm{OH}$ & 3.4 & 0.8 \\
\hline \multicolumn{3}{|l|}{ Cyclo } \\
\hline $\mathrm{C}_{17: 0}$ cyclo & 0.3 & 3.2 \\
\hline $\mathrm{C}_{19: 0}$ cyclo $\omega 8 c$ & 16.7 & 29.6 \\
\hline \multicolumn{3}{|l|}{ Unknown } \\
\hline ECL 14.959 & 0.8 & 0.2 \\
\hline \multicolumn{3}{|c|}{ Summed features ${ }^{*}$} \\
\hline 2 & 3.4 & 4.0 \\
\hline 3 & 0.7 & 1.1 \\
\hline
\end{tabular}

* Summed features represent groups of two or three fatty acids which could not be separated by GLC with the MIDI system. Summed feature 2 contained iso- $\mathrm{C}_{16: 1}$ and/or $\mathrm{C}_{14: 0} 3-\mathrm{OH}$. Summed feature 3 contained $\mathrm{C}_{16: 1} \omega 7 c$ and/or iso- $\mathrm{C}_{15: 0} 2-\mathrm{OH}$.

but not at $\mathrm{pH} 5.0$ or 10.5. Growth occurs in the presence of $0-5 \%(\mathrm{w} / \mathrm{v}) \mathrm{NaCl}$, with optimal growth at $0-1.0 \%(\mathrm{w} / \mathrm{v})$ $\mathrm{NaCl}$. Anaerobic growth does not occur on TSA, but occurs on TSA supplemented with nitrate. The predominant ubiquinone is Q-10. The major fatty acids $(>10 \%$ of total fatty acids) are $\mathrm{C}_{18: 1} \omega 7 c$ and $\mathrm{C}_{19: 0}$ cyclo $\omega 8 c$. Major polar lipids are phosphatidylcholine, phosphatidylglycerol, phosphatidylethanolamine, two aminolipids and two unidentified phospholipids. sym-Homospermidine, spermidine and putrescine are major polyamines. The DNA $\mathrm{G}+\mathrm{C}$ content of the type strain is $68.3 \mathrm{~mol} \%$ (determined by HPLC). Other phenotypic characteristics are given in Table 1.

The type strain, $\mathrm{K}_{106}{ }^{\mathrm{T}}\left(=\right.$ KCTC $12979^{\mathrm{T}}=$ CCUG $\left.54519^{\mathrm{T}}\right)$, was isolated from wastewater of a textile dye works at Daegu, Korea.

\section{Emended description of the genus Chelatococcus Auling et al. 1993}

The description of the genus Chelatococcus is as given by Auling et al. (1993) with the following amendments. Cells are cocci or rods. Utilization of NTA is positive or negative. The major fatty acids are $\mathrm{C}_{18: 1} \omega 7 c$ and $\mathrm{C}_{19: 0}$ cyclo $\omega 8 c$.
Major polar lipids are phosphatidylcholine, phosphatidylglycerol, phosphatidylethanolamine, two aminolipids and two unidentified phospholipids. sym-Homospermidine, spermidine and putrescine are major polyamines. The DNA G + C content is $63.3-68.3 \mathrm{~mol} \%$.

\section{Acknowledgements}

This work was supported by the 21C Frontier Program of Microbial Genomics and Applications (grant MG05-0401-2-0) from the Ministry of Science and Technology (MOST) of the Republic of Korea.

\section{References}

Auling, G., Busse, H.-J., Egli, T., El-Banna, T. \& Stackebrandt, E. (1993). Description of the Gram-negative, obligately aerobic, nitrilotriacetate (NTA)-utilizing bacteria as Chelatobacter heintzii, gen. nov., sp. nov., and Chelatococcus asaccharovorans, gen. nov., sp. nov. Syst Appl Microbiol 16, 104-112.

Busse, H.-J. \& Auling, G. (1988). Polyamine pattern as a chemotaxonomic marker within the Proteobacteria. Syst Appl Microbiol 11, 1-8.

Cowan, S. T. \& Steel, K. J. (1965). Manual for the Identification of Medical Bacteria. London: Cambridge University Press.

Egli, T., Weilenmann, H.-U., El-Banna, T. \& Auling, G. (1988). Gramnegative, aerobic, nitrilotriacetate-utilizing bacteria from wastewater and soil. Syst Appl Microbiol 10, 297-305.

Ezaki, T., Hashimoto, Y. \& Yabuuchi, E. (1989). Fluorometric deoxyribonucleic acid-deoxyribonucleic acid hybridization in microdilution wells as an alternative to membrane filter hybridization in which radioisotopes are used to determine genetic relatedness among bacterial strains. Int J Syst Bacteriol 39, 224-229.

Komagata, K. \& Suzuki, K. (1987). Lipid and cell-wall analysis in bacterial systematics. Methods Microbiol 19, 161-207.

Lányí, B. (1987). Classical and rapid identification methods for medically important bacteria. Methods Microbiol 19, 1-67.

Lee, K.-B., Liu, C.-T., Anzai, Y., Kim, H., Aono, T. \& Oyaizu, H. (2005). The hierarchical system of the 'Alphaproteobacteria': description of Hyphomonadaceae fam. nov., Xanthobacteraceae fam. nov. and Erythrobacteraceae fam. nov. Int J Syst Evol Microbiol 55, 1907-1919.

Minnikin, D. E., O’Donnell, A. G., Goodfellow, M., Alderson, G., Athalye, M., Schaal, A. \& Parlett, J. H. (1984). An integrated procedure for the extraction of bacterial isoprenoid quinones and polar lipids. J Microbiol Methods 2, 233-241.

Sasser, M. (1990). Identification of bacteria by gas chromatography of cellular fatty acids, Technical Note no. 101. Newark, DE: MIDI.

Schenkel, E., Berlaimont, V., Dubois, J., Helson-Cambier, M. \& Hanocq, M. (1995). Improved high-performance liquid chromatographic method for the determination of polyamines as their benzoylated derivatives: application to P388 cancer cells. $J$ Chromatogr B Biomed Appl 668, 189-197.

Stackebrandt, E. \& Goebel, B. M. (1994). Taxonomic note: a place for DNA-DNA reassociation and $16 \mathrm{~S}$ rRNA sequence analysis in the present species definition in bacteriology. Int J Syst Bacteriol 44, 846-849.

Tamaoka, J. \& Komagata, K. (1984). Determination of DNA base composition by reversed-phase high-performance liquid chromatography. FEMS Microbiol Lett 25, 125-128.

Wayne, L. G., Brenner, D. J., Colwell, R. R., Grimont, P. A. D., Kandler, O., Krichevsky, M. I., Moore, L. H., Moore, W. E. C., Murray, R. G. E. \& other authors (1987). International Committee on Systematic Bacteriology. 
Report of the ad hoc committee on reconciliation of approaches to bacterial systematics. Int J Syst Bacteriol 37, 463-464.

Yoon, J.-H., Kim, H., Kim, S.-B., Kim, H.-J., Kim, W. Y., Lee, S. T., Goodfellow, M. \& Park, Y.-H. (1996). Identification of Saccharomonospora strains by the use of genomic DNA fragments and rRNA gene probes. Int J Syst Bacteriol 46, 502-505.
Yoon, J.-H., Lee, S. T. \& Park, Y.-H. (1998). Inter- and intraspecific phylogenetic analysis of the genus Nocardioides and related taxa based on 16S rRNA gene sequences. Int J Syst Bacteriol 48, 187-194.

Yoon, J.-H., Kang, K. H. \& Park, Y.-H. (2003). Psychrobacter jeotgali sp. nov., isolated from jeotgal, a traditional Korean fermented seafood. Int J Syst Evol Microbiol 53, 449-454. 